\title{
Presence of Anaplerotic Reactions and Transamination, and the Absence of the Tricarboxylic Acid Cycle in Mollicutes
}

\author{
By JOHN T. MANOLUKAS, ${ }^{1}$ MICHAEL F. BARILE, ${ }^{2}$ \\ DONNA K. F. CHANDLER ${ }^{2}$ AND J. DENNIS POLLACK ${ }^{1 *}$ \\ ${ }^{1}$ Department of Medical Microbiology and Immunology, The Ohio State University, Columbus, \\ Ohio 43210, USA \\ 2 Division of Bacterial Products, National Center for Drugs and Biologics, Food and Drug \\ Administration, Bethesda, Maryland 20205, USA
}

(Received 1 July 1987; revised 12 October 1987)

Cell extracts of the fermentative Mollicutes Acholeplasma laidlawii B-PG9, Acholeplasma morum S2, Mycoplasma capricolum 14, Mycoplasma gallisepticum S6, Mycoplasma pneumoniae FH, Mycoplasma hyopneumoniae $\mathbf{J}$ and $M$. genitalium G-37, and the non-fermentative Mycoplasma hominis PG-21, Mycoplasma hominis 1620 and Mycoplasma bovigenitalium PG-11 were examined for 39 cytoplasmic enzyme activities associated with the tricarboxylic acid (TCA) cycle, transamination, anaplerotic reactions and other enzyme activities at the pyruvate locus. Malate dehydrogenase (EC 4.2.1.2) was the only TCA-cycle-associated enzyme activity detected and it was found only in the eight Mycoplasma species. Aspartate aminotransferase (EC 2.6.1.1) activity was detected in all Mollicutes tested except $M$. gallisepticum S6. Malate synthetase (EC 4.1.3.2) activity, in the direction of malate formation, was found in the eight Mycoplasma species, but not in any of the Acholeplasma species. Phosphoenolpyruvate (PEP) carboxylase (EC 4.1.1.31) was detected in the direction of oxaloacetate (OAA) formation in both Acholeplasma species, but not in any of the Mycoplasma species. Pyruvate carboxylase (EC 6.4.1.1), pyruvate kinase (EC 2.7.1.40), pyruvate dehydrogenase (EC 1.2.4.1) and lactate dehydrogenase (EC 1.1.1.27) activities were found in all ten Mollicutes tested. No activities were detected in any of the ten Mollicutes for aspartase (EC 4.3.1.1), malic enzyme (EC 1.1.1.40), PEP carboxytransphosphorylase (EC 4.1.1.38), PEP carboxykinase (EC 4.1.1.32) or pyruvate orthophosphate dikinase (EC 2.7.9.1). In these TCA-cycle-deficient Mollicutes the pyruvate-OAA locus may be a point of linkage for the carbons of glycolysis, lipid synthesis, nucleic acid synthesis and certain amino acids. $\mathrm{CO}_{2}$ fixation appears obligatory in the Acholeplasma species and either $\mathrm{CO}_{2}$ fixation or malate synthesis appears obligatory in the Mycoplasma species.

\section{INTRODUCTION}

The Mollicutes, a class of prokaryotic organisms characterized by the lack of a cell wall, can be divided into fermentative and non-fermentative groups based on their carbohydrate metabolism (Smith, 1971). The fermentative group produces acid from carbohydrates such as glucose (Tourtellotte \& Jacobs, 1960). In these fermentative Mollicutes, glucose is oxidized to acetate and $\mathrm{CO}_{2}$, and lactate is the major end product of glycolysis (Gill, 1960; Neimark \& Pickett, 1960; Castrejon-Diez et al., 1963; Smith, 1971; Beaman \& Pollack, 1981; Reinards et al., 1981). The non-fermentative group does not significantly lower the $\mathrm{pH}$ of the culture medium and some of these organisms are known to oxidize fatty acids and alcohols (Lynn, 1960; VanDemark \& Smith, 1965; Beaman \& Pollack, 1983).

Abbreviations: TCA cycle, tricarboxylic acid cycle; PEP, phosphoenolpyruvate; OAA, oxaloacetate; MDH, malate dehydrogenase; PFK, phosphofructokinase. 
Apart from the report of VanDemark \& Smith (1964b), there is little additional evidence for the presence of the tricarboxylic acid (TCA) cycle in non-fermentative Mollicutes (Holmes \& Pirie, 1932; Leece \& Morton, 1954; Tourtellotte \& Jacobs, 1960). The non-fermentative strain previously designated Mycoplasma hominis 07, now known as Mycoplasma arthritidis 07, was reported to be capable of oxidizing TCA intermediates (VanDemark \& Smith, 1964b). The presence of the TCA cycle in the non-fermentative 07 strain was compatible with the observations that the same strain had cytochrome pigments and evidence for the presence of oxidative phosphorylation activity (VanDemark \& Smith, 1964a). However, the relationship was diminished by our contrary finding that cytochrome pigments are absent from the 07 strain and from other Mollicutes (Pollack et al., 1981), and that quinones are present only in trace amounts in these organisms (Hollaender et al., 1977).

Parenthetically, a $\mathrm{Fe} / \mathrm{Cu}$ flavoprotein (FMN) dehydrogenase has been found and purified in Acholeplasma laidlawii (Reinards et al., 1981) and a similar flavoprotein (FAD) dehydrogenase has been purified from Mycoplasma capricolum 14 (Klomkes et al., 1985). Although the hypothesis is untested, these dehydrogenases might act as electron acceptors leading to the conservation of energy in a manner analogous to the activity of a Site-I-like locus of classical electron transport in mitochondria, i.e., there may be some limited form of oxidative phosphorylation in these Mollicutes.

The fermentative Mycoplasma mycoides subsp. mycoides cannot metabolize citrate, 2oxoglutarate, succinate or fumarate (Rodwell \& Rodwell, 1954) and strains of the fermentative A. laidlawii lack malate dehydrogenase (MDH) (Lanham et al., 1980). The absence of such activities supported the concept that the fermentative Mollicutes may lack the TCA cycle while the non-fermentative Mollicutes, at least $M$. arthritidis (M. hominis) 07, have the TCA cycle. More recently, the reports of the presence of $\mathrm{MDH}$ activity in some fermentative Mollicutes suggests that at least part of the TCA cycle might be present in such organisms (Salih et al., 1983; Cocks et al., 1985).

In preliminary studies we were unable to confirm the presence of the TCA cycle in other strains of Mycoplasma hominis, and decided to reinvestigate such metabolism in Mollicutes. In this study, we investigated enzyme activities associated with the TCA cycle, transamination, anaplerotic and other enzyme activities at the pyruvate locus in ten Mollicutes. The Mollicutes we studied were the fermentative Acholeplasma laidlawii B-PG9, Acholeplasma morum S2, Mycoplasma capricolum 14, Mycoplasma gallisepticum S6, Mycoplasma pneumoniae FH, Mycoplasma hyopneumoniae J, M. genitalium G-37 and the non-fermentative Mycoplasma hominis PG-21, Mycoplasma hominis 1620 and Mycoplasma bovigenitalium PG-11.

\section{METHODS}

Organisms. Ten Mollicutes representing acholeplasmas and both fermentative and non-fermentative mycoplasmas were selected. From our stock collections we chose two acholeplasmas - Acholeplasma laidlawii B-PG9 and Acholeplasma morum S2 - the fermentative mycoplasmas Mycoplasma capricolum 14, Mycoplasma gallisepticum S6 and Mycoplasma pneumoniae FH, and the non-fermentative Mycoplasma hominis PG-21, Mycoplasma hominis 1620 and Mycoplasma bovigenitalium PG-11. Tbe fermentative Mycoplasma genitalium G-37 was obtained from V. V. Tryon, University of Texas Health Science Center at San Antonio, San Antonio, Tx., USA. The fermentative Mycoplasma hyopneumoniae J was obtained from R. F. Ross, Iowa State University, Ames, Ia., USA. Escherichia coli ATCC 29522, Streptococcus faecium ATCC 6051 and a recent isolate of Pseudomonas aeruginosa, identified by University Hospital, The Ohio State University, USA, were also examined.

Media and growth conditions. Unless indicated organisms were grown statically in 4-6 cm deep layers in our modification of Edward medium at $37^{\circ} \mathrm{C}$ until mid-exponential phase (1-4 d) (Beaman \& Pollack, 1981). For the growth of the fermentative Mollicutes, the media were supplemented with $0-0.5 \%$ heat inactivated horse serum for $A$. laidlawii and $A$. morum, and with $5 \%(\mathrm{v} / \mathrm{v})$ serum for $M$. capricolum and $M$. gallisepticum. M. pneumoniae and $M$. bovigenitalium were grown in a similar medium containing $0.002 \%$ phenol red, $5 \%(\mathrm{v} / \mathrm{v})$ fresh yeast extract (Flow Laboratories) instead of powdered yeast extract, and $10 \%(\mathrm{v} / \mathrm{v})$ heat inactivated horse serum. M. hominis strains were grown in media similar to that used for $M$. pneumoniae but supplemented with $0.15 \%$ arginine. $\mathrm{HCl}$, while the fresh yeast extract concentration was reduced to $1 \%$ and the $\mathrm{pH}$ was $6 \cdot 8-7 \cdot 0 . \mathrm{M}$. genitalium was grown in 
Hayflick medium (Lipman et al., 1969) supplemented with $20 \%$ (v/v) heat inactivated horse serum and $0.04 \%$ phenol red. M. hyopneumoniae was grown at $36^{\circ} \mathrm{C}$ in Friis broth culture (Friis, 1975) containing $10 \%(\mathrm{v} / \mathrm{v})$ acid adjusted swine serum (Slavik \& Switzer, 1972). M. hyopneumoniae and A. laidlawii were also grown with constant shaking (approximately 100 r.p.m., $10 \mathrm{~cm}$ stroke, model 3590 , Labline Instruments). $M$. hominis 1620 was grown with and without sparging at a rate of 161 sterile air $\mathrm{h}^{-1}(1 \text { medium })^{-1}$ for $1-2 \mathrm{~d}$. $M$. pneumoniae was grown attached to plastic $150 \mathrm{~cm}^{2}$ tissue culture flasks. $M$. pneumoniae organisms were harvested by pouring off the culture medium, scraping the attached organisms into kappa buffer (Pollack et al., 1970) and centrifuging at $12000 \mathrm{~g}$ for $30 \mathrm{~min}$ at $4^{\circ} \mathrm{C}$.

Preparation of cell extracts. Cell preparations were made essentially as previously described (Pollack, 1975, 1983). Cells were collected and washed by centrifugation. Washed cells were lysed by osmotic shock or by explosive decompression in a Parr-Bomb. Cells lysates were fractionated by centrifugation and then dialysed.

Enzyme assays. In cytoplasmic fractions from each of 10 Mollicutes, 39 enzyme activities comprising or associated with the TCA cycle, transamination, anaplerotic and other activities at the pyruvate locus were assayed spectrophotometrically (model 260, Gilford). Reaction mixtures contained $2.3 \times 10^{-2}-9 \cdot 1 \times 10^{2} \mu \mathrm{g}$ protein ml ${ }^{-1}$ and the assays were done aerobically and in some cases anaerobically in nitrogen or helium. When no activity was detected with our cytoplasmic extracts at a reaction mixture concentration of $70 \%(v / v)$, we added approximately $0.001 \mathrm{U}$ of commercially available purified enzyme (Sigma). This was a test for the sensitivity and appropriateness of our assay conditions, and the presence of inhibitors in the Mollicute cytoplasmic extract. HEPES (Research Organics) was the only buffer used in our studies. Protein was determined using the G-250 dye reagent formulated by Bio-Rad. Pyrophosphate $\left(\mathbf{P P}_{\mathrm{i}}\right)$ was assayed using a pyrophosphate assay kit (Sigma) according to the manufacturer's directions.

Enzymes of the TCA cycle. (i) Citrate synthase (EC 4.1.3.7) was assayed by both the methods of Srere (1969) and Stitt (1983a). (ii) Aconitase (EC 4.2.1.3) was assayed by a modification of the method of Goldberg \& Ellis (1983). The reaction mixture $(1.0 \mathrm{ml})$ contained $100 \mathrm{mM}-\mathrm{HEPES} / \mathrm{NaOH}(\mathrm{pH} 7.4), 1.7 \mathrm{mM}-\mathrm{MnCl}_{2}, 0.15 \mathrm{~mm}-$ $\mathrm{NADP}^{+}, 1 \mathrm{U}$ isocitrate dehydrogenase and cell extract. The reaction was started with $5 \mathrm{~mm}$-citric acid. (iii) Isocitrate dehydrogenase (EC 1.1.1.42) was assayed by the method of Goldberg \& Ellis (1983). (iv) 2Oxoglutarate dehydrogenase (EC 1 2.4.2) was assayed by the method of Reed \& Mukherjee (1963). (v) Succinate synthase (EC 6.2.1.5) was assayed by the method of Bridger et al. (1969). (vi) Succinate dehydrogenase (EC 1.3.99.1) was assayed by the methods of Reddy \& Weber (1986). (vii) Fumarate reductase (EC 1.3.1 .6) was assayed by the methods of George \& Smibert (1982). (viii) Fumarase (EC 4.2.1.2) was assayed by the procedure of Stitt (1983b). (ix) Malate dehydrogenase (EC 1.1.1.37) was assayed by the method of Yoshida (1969).

Transaminase, anaplerotic and other activities at the pyruvate locus. (i) Aspartate aminotransferase (EC 2.6.1.1) was assayed by the procedure of Rej \& Horder $(1983)$ at $37^{\circ} \mathrm{C}$. (ii) Aspartase (EC 4.1.3.2) was assayed by the procedure of Williams \& Lartigue (1969). (iii) Malic enzyme (EC 1.1.1.40) was assayed according to the method of Hsu \& Lardy (1969). (iv) Phosphoenolpyruvate (PEP) carboxylase (EC 4.1.1.31) was assayed according to the method of Smith (1968). We also assayed for $\mathrm{CO}_{2}$ fixation using $0.4 \mu \mathrm{Ci}(14.8 \mathrm{kBq}) \mathrm{NaH}^{14} \mathrm{CO}_{3}$ in each reaction mixture [specific activity $0.1 \mathrm{mCi} \mathrm{mmol}^{-1}\left(3.7 \mathrm{MBq} \mathrm{mmol}^{-1}\right)$; Research Products International], by the method of Cox \& Baugh (1976). (v) PEP carboxytransphosphorylase (EC 4.1.1.38) and PEP carboxykinase (EC 4.1.1.32) were assayed by a modification of the procedure of Smith (1968). The basic reaction mixture $(1.0 \mathrm{ml})$ contained $100 \mathrm{~mm}$-HEPES/NaOH (pH 7.4), $6 \mathrm{mM}$-PEP, $5 \mathrm{mM}-\mathrm{MgCl}_{2}$ or $\mathrm{MnCl}_{2}, 0.1 \mathrm{U}$ malate dehydrogenase (MDH), $0.15 \mathrm{mM}-\mathrm{NADH}$ and cell extract. For the PEP carboxytransphosphorylase assay, $5 \mathrm{mM}-\mathrm{KH}_{2} \mathrm{PO}_{4}\left(\mathrm{P}_{\mathrm{i}}\right)$ was also added and for the PEP carboxykinase assay either 4 mM-ADP or $4 \mathrm{mM}$-GDP was added and the reactions were started by the addition of $10 \mathrm{mM}-\mathrm{NaHCO}_{3}$. (vi) Pyruvate carboxylase (EC 6.4.1.1) was assayed by the method of Holdsworth \& Bruck (1977). Also, ATP formed by this reaction was measured directly by following the formation of NADPH at $340 \mathrm{~nm}$ in a mixture $(1.0 \mathrm{ml})$ containing $100 \mathrm{~mm}-\mathrm{HEPES} / \mathrm{NaOH}(\mathrm{pH} 7.4), 1.8 \mathrm{~mm}$-glucose, $0.1 \mathrm{U}$ hexokinase, $10 \mathrm{~mm}$-glucose 6-phosphate, $0.1 \mathrm{U}$ glucose-6-phosphate dehydrogenase, $15 \mathrm{~mm}$-NADP+, $4 \mathrm{~mm}$ ADP, $140 \mathrm{~mm}$-oxaloacetate (OAA), $5 \mathrm{~mm}-\mathrm{KH}_{2} \mathrm{PO}_{4}\left(\mathrm{P}_{\mathrm{i}}\right)$ and cytoplasmic extract. (vii) Pyruvate dehydrogenase (EC 1.2.4.1) was assayed by the procedure of McGarrity et al. (1984). Pyruvate kinase (EC 2.7.1.40) was assayed by the procedure of Bucher \& Pfleiderer (1955). (viii) Pyruvate orthophosphate dikinase (EC 2.7.9.1) was assayed by the procedure of Ernst et al. (1986). (ix) Lactate dehydrogenase (EC 1.1.1.27) was assayed by the procedure of Kornberg (1955). (x) Malate synthase (EC 4.1.3.2) was assayed by the procedure of Dixon \& Kornberg (1962).

Statistical analysis. Each enzyme activity in each batch of cells was assayed at three to five concentrations of cell extract to determine the maximum specific activity (rate). The mean rates and SD values we report were calculated from the individual rates obtained from each of six to fifteen different batches of cells for $A$. laidlawii B-PG9, $A$. morum S2, $M$. capricolum 14 and $M$. gallisepticum S6, and from three batches of $M$. hyopneumoniae J, $M$. pneumoniae FH, $M$. hominis 1620 and $M$. bovigenitalium PG-11. Two batches of $M$. hominis PG-21 and one batch of M. genitalium G-37 were examined. 
Table 1. Enzyme activities in extracts of the Acholeplasma and non-fermentative Mycoplasma species

Enzyme activity is expressed as $\mathrm{nmol}$ product synthesized $\min ^{-1}$ (mg protein) $)^{-1}$ (mean $\pm \mathrm{SD}$ ).

$$
\text { Enzyme Reaction }
$$

Malate dehydrogenase

\section{4}

15

Aspartate

aminotransferase

Malate synthase

PEP carboxylase

Pyruvate carboxylase

Pyruvate dehydrogenase

Pyruvate kinase

Lactate dehydrogenase
A. laidlawii $\dagger$

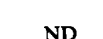

ND

$$
\begin{gathered}
26 \cdot 6 \pm 0 \cdot 3 \\
426 \pm 12
\end{gathered}
$$$$
\text { ND }
$$$$
880 \pm 49
$$$$
2.9 \pm 0.1
$$$$
0.30 \pm 0.02
$$$$
13.8 \pm 0.2
$$$$
1.9 \pm 0.03
$$

A. $m$

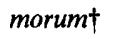

ND
ND

\section{$M$}

\section{$M$. hominis $\quad M$. hominis $1620 \dagger$ PG-21}

$212 \pm 3$
$925 \pm 6$
$826 \pm 4$
$53 \pm 2$
$412 \pm 14$
ND
$4500 \pm 36$
$25 \pm 1$
$11.6 \pm 0.11$
$2.50 \pm 0.03$
$9.2 \pm 0.1$
$102 \pm 2$
$756 \pm 4$
$1.3 \pm 0.03$

$111 \pm 9$
$713 \pm 15$

127

640

$\begin{array}{cr}789 \pm 9 & 650 \\ 19 \pm 1 & 12 \\ 214 \pm 2 & 423 \\ \text { ND } & \text { ND } \\ 1150 \pm 14 & 1290 \\ 16 \pm 1 & 31 \\ 5 \cdot 3 \pm 0 \cdot 8 & 17 \\ 1 \cdot 30 \pm 0.02 & 2 \\ 2 \cdot 1 \pm 0.01 & 3 \\ 73 \pm 1 & 88 \\ 94 \pm 6 & 78 \\ 3 \cdot 2 \pm 0.02 & 2\end{array}$

$1.3 \pm 0.03$

$3.2 \pm 0.02$ 


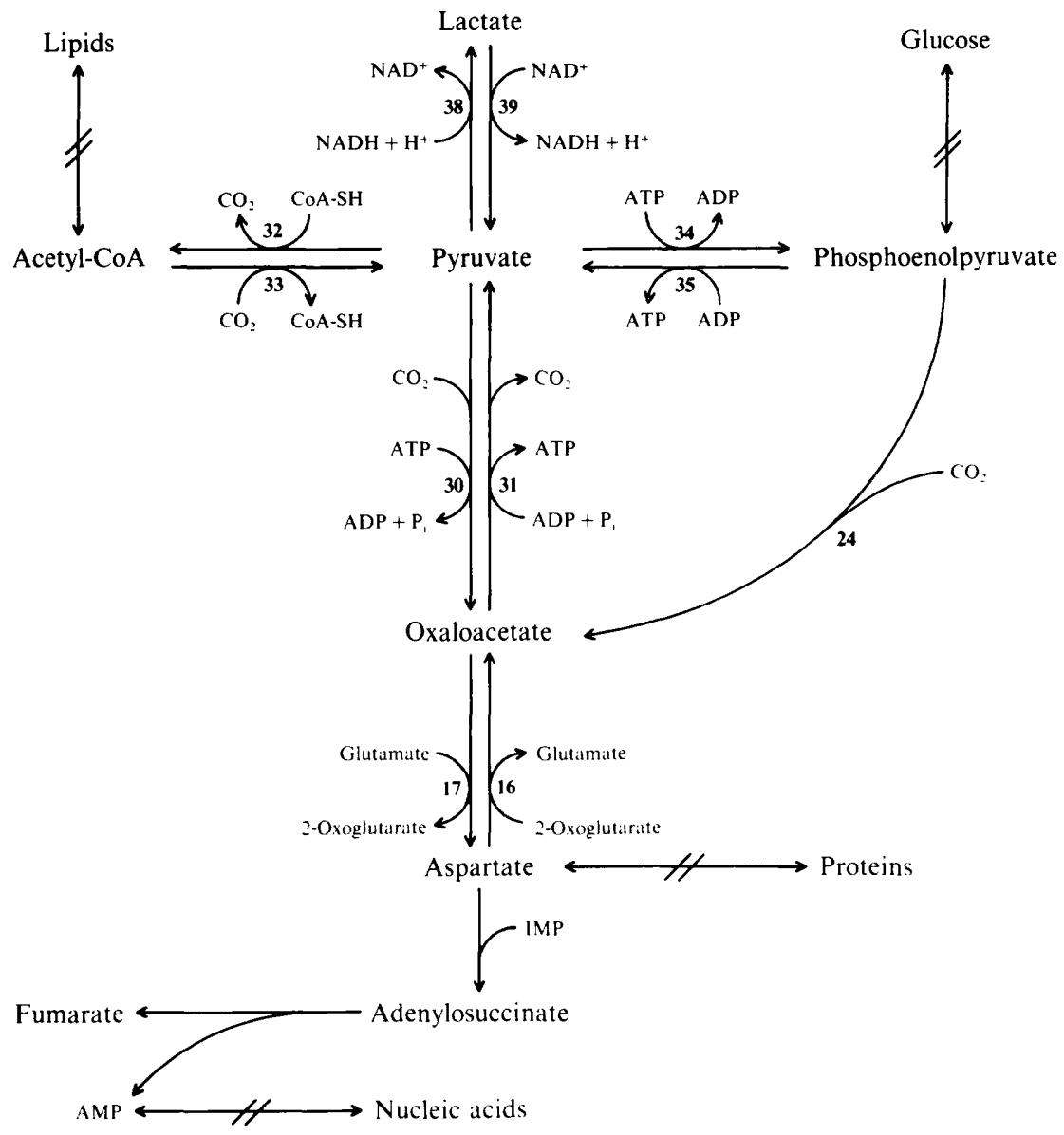

Fig. 1. Schematic diagram of the enzyme activities and pathways detected in extracts of $A$. laidlawii B-PG9 and $A$. morum $\mathbf{S}$. The enzyme assays and abbreviations are described in Methods. The reaction nos refer to the same enzyme reactions numbered and described in Table 1. The lines with a pair of diagonal slashes represent reaction sequences presumably present but not investigated in this study.

\section{RESULTS}

Enzyme activities associated with the TCA cycle

In the cytoplasmic extracts from both Acholeplasma species we detected no enzyme activities associated with the TCA cycle. All Mycoplasma species extracts contained MDH activity (Tables 1 and 2, reactions 14 and 15), but lacked any other activity associated with the TCA cycle. As a test for the possible inhibition of enzyme expression by our enriched medium $E$. coli, $P$. aeruginosa and $S$. faecium were grown under the same conditions as the Mollicutes. With the exception of citrate synthetase in Streptococcus faecium, we detected all nine of the enzyme activities of the TCA cycle in these three bacteria. As a test for the effects of aeration on enzyme activities, $A$. laidlawii and $M$. hominis 1620 were both grown statically and also with either shaking or sparging. We found no difference in the enzyme patterns found in either Mollicute whether grown statically or with aeration.

\section{Transamination activity}

The results of our assay for transaminase activity are shown in Tables 1 and 2 and in Figs 1 and 2 (reactions 16 and 17). With the exception of M. gallisepticum S6, all of the Mollicutes tested possessed aspartate aminotransferase activity in both directions. 


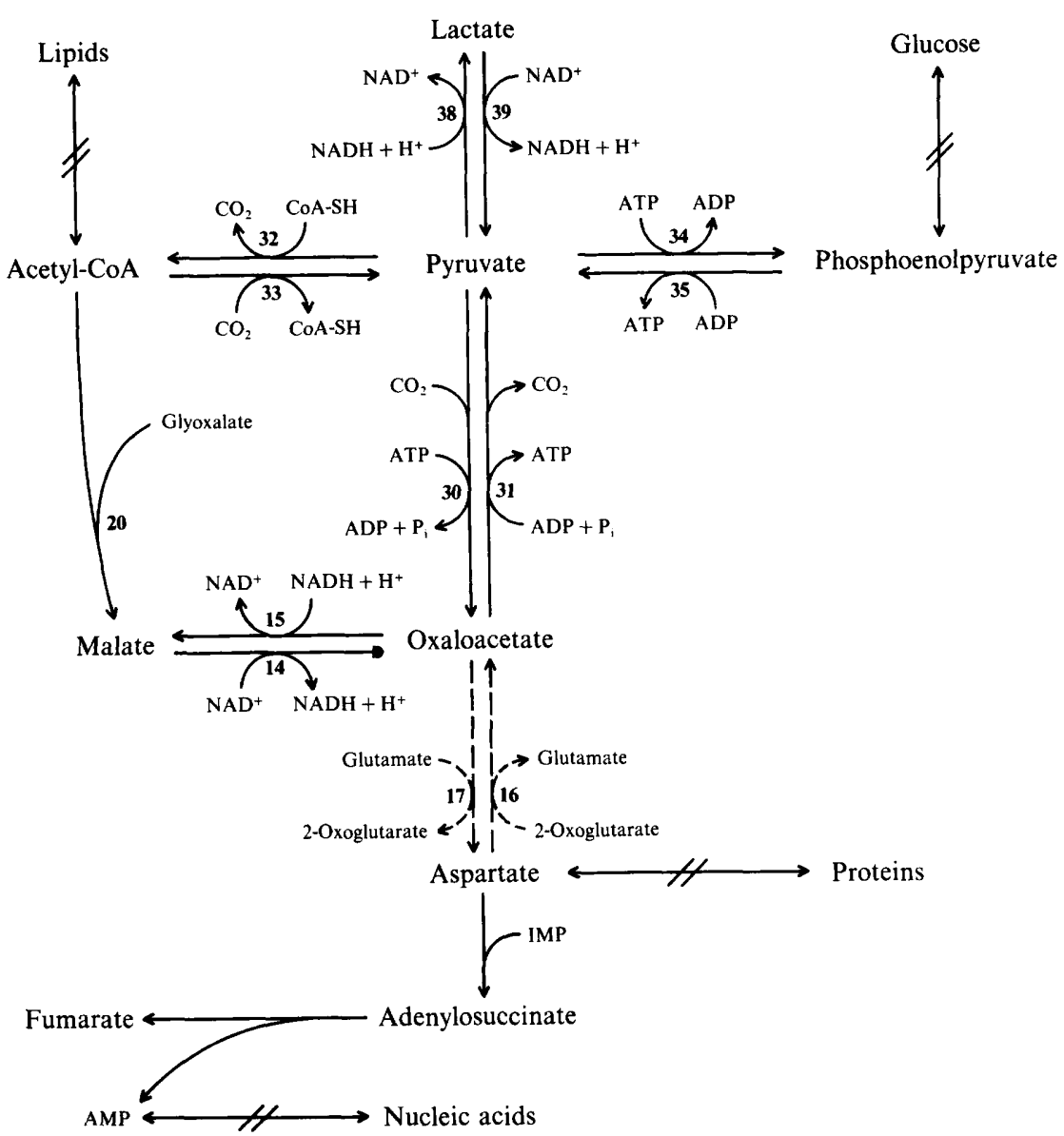

Fig. 2. Schematic diagram of the enzyme activities and pathways detected in extracts of $M$. capricolum 14, M. gallisepticum S6, M. pneumoniae FH, M. genitalium G-37, $M$. hyopneumoniae J, M. hominis $\mathrm{PG}-21$, $M$. hominis 1620 and $M$. bovigenitalium PG-11. The enzyme assays and abbreviations are described in Methods. The reaction nos refer to the same enzyme reactions numbered and described in Tables 1 and 2. The dashed lines at the aspartate aminotransferase locus (reactions 16 and 17) indicate that the reactions are present in all organisms except $M$. gallisepticum. The lines with a pair of diagonal slashes represent reaction sequences presumably present but not investigated in this study.

\section{Anaplerotic and other activities at the pyruvate locus}

No aspartase, malic enzyme, PEP carboxytransphosphorylase, PEP carboxykinase or pyruvate orthophosphate dikinase activities were detected in any of the Mollicutes tested.

PEP carboxylase in the direction of OAA formation (Table 1 and Fig. 1, reaction 24) was detected in both of the Acholeplasma species, but was not detected in either the fermentative or non-fermentative Mycoplasma species. This indicated that the Acholeplasma species apparently fixed $\mathrm{CO}_{2}$ by converting PEP and $\mathrm{CO}_{2}$ to OAA. This occurred without the addition of $\mathrm{P}_{\mathrm{i}}$ or

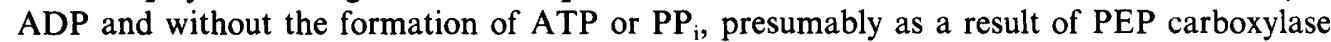
activity, as neither PEP carboxytransphosphorylase or PEP carboxykinase were detectable.

We obtained more direct evidence for $\mathrm{CO}_{2}$ fixation in $A$. laidlawiii. Extracts, in the presence of $\mathrm{MnCl}_{2}$ and PEP, could incorporate $\mathrm{NaH}^{14} \mathrm{CO}_{3}$ radioactivity into material which was not volatilized from solutions of $\mathrm{pH} \leq 2 \cdot 0$. A radioactive dinitrophenylhydrazine derivative of this material co-migrated with the dinitrophenylhydrazone of OAA : thus OAA was synthesized in our PEP carboxylase reaction (unpublished data). We found, as did Beaman \& Pollack (1984), 
that the PEP carboxylase activity in extracts from five different cell batches of $A$. laidlawii was $8.25 \pm 0.87 \mathrm{nmol}$ OAA synthesized $\min ^{-1}(\mathrm{mg} \text { protein })^{-1}$.

All the Mycoplasma species tested contained malate synthase activity in the direction of malate formation (Tables 1 and 2, Fig. 2, reaction 20). In the Acholeplasma species no malate synthase activity was detected. No activity was detected in the direction of glyoxalate formation in any of the Mollicutes.

The extracts from all ten Mollicutes had pyruvate carboxylase activity in the direction of OAA formation. In the reverse direction of this reaction, where ATP is synthesized, we measured ATP synthesis directly and found it (Tables 1 and 2, Figs 1 and 2, reactions 30 and 31). All ten Mollicutes had pyruvate kinase activity in both directions and lactate dehydrogenase activity in both directions (Tables 1 and 2, Figs 1 and 2, reactions 34, 35, 38 and 39).

$A$. laidlawii and $M$. gallisepticum extracts have pyruvate dehydrogenase activity (McGarrity $e t$ al., 1984). All other Mollicutes we tested also contained this enzyme activity (Tables 1 and 2, Figs 1 and 2, reactions 32 and 33).

\section{DISCUSSION}

Our data corroborates the view that the fermentative Mollicutes lack the complete TCA cycle and indicates that the non-fermentative Mollicutes also lack a complete TCA cycle. MDH was the only detectable activity associated with the TCA cycle and was found only in the Mycoplasma species, whether fermentative or non-fermentative.

The inability to detect MDH activity in Acholeplasma species is consistent with the findings of Lanham et al. (1980) who, using isoenzyme electrophoretic analysis, were unable to detect MDH activity. However, Salih et al. (1983) detected weak MDH activity in $A$. laidlawii by the same technique; they concluded that the low activity was due to enzyme instability. This may account for our inability to detect $\mathrm{MDH}$ activity in A. laidlawii.

Aspartate aminotransferase activity was not found in $M$. mycoides subsp. mycoides (Rodwell, 1960), but has been reported in $A$. laidlawii (Lanham et al., 1980). However, Razin (1963) failed to detect this activity in $A$. laidlawii. We detected aspartate aminotransferase activity in all Mollicutes tested except $M$. gallisepticum; this latter observation is in conflict with Gill (1960). As the enzyme might be unstable and destroyed during preparation of the cytoplasmic extract, we assayed enzyme activity before and after ultracentrifugation and dialysis, but still failed to detect activity. Though malate synthase activity was reported absent in non-fermentative $M$. arthritidis (M. hominis) 07 (VanDemark \& Smith, 1964b), we detected malate synthase activity in both non-fermentative and fermentative Mycoplasma species but only in the direction of malate synthesis.

Of the anaplerotic reactions tested, pyruvate carboxylase was found in all ten Mollicutes and PEP carboxylase in both Acholeplasma species but not in any Mycoplasma species. It was surprising not to find either PEP carboxytransphosphorylase activity or pyruvate orthophosphate dikinase activity in $A$. laidlawii or $A$. morum since these organisms have been reported to possess a $\mathrm{PP}_{\mathrm{i}}$-dependent phosphofructokinase (PFK) (Pollack \& Williams, 1986), and the former activities were reported to be present in organisms with a $\mathrm{PP}_{\mathrm{i}}$-dependent PFK (Wood et al., 1977; Tryon \& Pollack, 1984).

Acholeplasma and Mycoplasma species each have two paths from PEP to OAA. One path, present in both genera, proceeds from PEP to pyruvate via pyruvate kinase with a gain of one ATP, then from pyruvate to OAA via pyruvate carboxylase with a loss of one ATP (Figs 1 and 2, reactions 35 and 30 ). The Acholeplasma species have an alternate path to OAA directly from PEP without an intervening pyruvate and the concomitant gain and loss of ATP. This alternate carboxylation path proceeds via PEP carboxylase to OAA (Fig. 1, reaction 24). Therefore, neither path from PEP to OAA in Acholeplasma species yields net ATP. The two acholeplasmas having pyruvate dehydrogenase, but lacking malate synthase apparently use acetyl-CoA for lipid rather than malate synthesis. The alternate path in the Mycoplasma species proceeds from PEP to pyruvate via pyruvate kinase, with the gain of one ATP, then from pyruvate to acetylCoA by pyruvate dehydrogenase, from acetyl-CoA to malate, then to OAA by malate synthase 
and MDH, respectively (Fig. 2, reactions $35,32,20$ and 14). Therefore, the alternate path to OAA in Mycoplasma species yields ATP.

This longer and more energetically favourable path in Mycoplasma species may be regulated by cellular levels of $\mathrm{CoA}-\mathrm{SH}$, glyoxalate and $\mathrm{NAD}^{+}$. However, when $\mathrm{CoA}-\mathrm{SH}, \mathrm{NAD}^{+}$or glyoxalate are limiting, pyruvate carboxylase activity may be important in the synthesis of OAA, even though there is no gain of ATP. The source of glyoxalate in the Mollicutes is unknown. We have not detected isocitrate lyase activity, nor the glyoxalate cycle in any Mollicutes (unpublished data).

The absence of aspartate aminotransferase activity in $M$. gallisepticum $\mathrm{S} 6$ denotes that this metabolic point is disconnected from glycolysis and that there may be no passage of glycolytic carbons via pyruvate and OAA to amino acids, and hence to proteins. Although there are no studies examining the linkage of aspartate to the synthesis of amino acids and proteins in the Mollicutes, there are data showing that aspartate may be required in the synthesis of AMP by Mollicutes, and, therefore, a linkage to nucleic acids appears to be established (Figs 1 and 2) (Pollack et al., 1981; Tryon \& Pollack, 1985). However, this hypothesis includes as a corollary the accumulation of fumarate. Although we have detected transitory low levels of fumarate in cells, we know of no role for fumarate in the metabolism of Mollicutes (unpublished data). Stimulation of growth by 2-oxoglutarate (Leece \& Morton, 1954; Tourtellotte \& Jacobs, 1960) might indicate growth stimulating transaminase activity rather than the presence of the TCA cycle.

As we used crude enzyme preparations and competing reactions cannot be excluded, the rates in Table 1 should be viewed with caution, and used to indicate the presence or absence of activity only.

We detected no difference between the enzyme patterns of the non-fermentative and the fermentative Mycoplasma species. The pattern detected for the Mycoplasma species is different from that of the Acholeplasma species.

Our data have thus categorized a number of metabolic interchange activities at the pyruvateOAA locus. The interchanges may be controlled by the compounds involved, some of whiche.g. acetyl-CoA, ATP and PEP - are already known to be involved in regulation of the central pathways.

We are indebted to V. V. Tryon for help in preparing cell pellets of $M$. genitalium G-37, and to T. Young and R. Ross for help in preparing $M$. hyopneumoniae $\mathrm{J}$. We wish to express our appreciation to the Graduate School of The Ohio State University and its Dean for their encouragement and generous support.

\section{REFERENCES}

Beaman, K. D. \& Pollack, J. D. (1981). Adenylate energy charge in Acholeplasma laidlawii. Journal of Bacteriology 146, 1055-1058.

Beaman, K. D. \& Pollack, J. D. (1983). Synthesis of adenylate nucleotides by Mollicutes (mycoplasmas). Journal of General Microbiology 129, 3103-3110.

Beaman, K. D. \& Pollack, J. D. (1984). Enzymatic assimilation of ${ }^{14} \mathrm{C}$ from $\mathrm{NaH}^{14} \mathrm{CO}_{3}$ by extracts of Acholeplasma laidlawii B-PG9. Yale Journal of Biology and Medicine 57, 897.

Bridger, W. A., Ramaley, R. F. \& Boyer, P. D. (1969). Succinyl coenzyme A synthetase from Escherichia coli. Methods in Enzymology 13, 70-74.

Bucher, T. \& Pfleiderer, G. (1955). Pyruvate kinase from muscle. Methods in Enzymology 1, 435440.

Castrejon-Diez, J., Fisher, T. N. \& Fisher, E., II. (1963). Glucose metabolism of two strains of Mycoplasma laidlawii. Journal of Bacteriology 86, 627-636.

Cocks, B. G., Brake, F. A., Mitchell, A. \& Finch, L. R. (1985). Enzymes of intermediary carbohydrate metabolism in Ureaplasma urealyticum and Mycoplasma mycoides subsp. mycoides. Journal of General Microbiology 131, 2128-2135.

Cox, D. L. \& BAUGH, C. L. (1976). Carboxylation of phosphoenolpyruvate by extracts of Neisseria gonorrhoeae. Journal of Bacteriology 129, 202-206.

Dixon, G. H. \& Kornberg, H. L. (1962). Malate synthetase from baker's yeast. Methods in Enzymo$\log y$ 5, 633-637.

ERNST, S. M., Budde, R. J. A. \& Chollet, R. (1986). Partial purification and characterization of pyruvate orthophosphate dikinase from Rhodospirillum rubrum. Journal of Bacteriology 165, 483-488.

FRIIS, N. F. (1975). Some recommendations concerning primary isolation of Mycoplasma suipneumoniae and Mycoplasma flocculare: a survey. Nordisk Veterinaermedicin 27, 337-339.

George, H. A. \& Smibert, R. M. (1982). Fumarate reduction and product formation by the Reiter strain of Treponema phagedenis. Journal of Bacteriology 152, 1049-1059.

GILL, J. W. (1960). Culture and metabolism of 
Mycoplasma gallisepticum. Journal of Bacteriology 83, 213-218.

GOLDBERG, D. M. \& Ellis, G. (1983). Isocitrate dehydrogenase. In Methods in Enzymatic Analysis, 3rd edn, vol. 3, pp. 183-188. Edited by H. U. Bergmeyer. New York: Academic Press.

Holdsworth, E. S. \& BruCK, K. (1977). Enzymes concerned with $\alpha$-carboxylation in marine phytoplankton. Achives of Biochemistry and Biophysics 182, 87-94.

Hollaender, R., Wolf, G. \& Mannheim, W. (1977). Lipoquinones of some bacteria and mycoplasmas, with considerations on their functional significance. Antonie van Leeuwenhoek 43, 177-185.

Holmes, B. E. \& Pirie, A. (1932). Growth and metabolism of the bovine pleuropneumonia virus. British Journal of Experimental Pathology 13, 364 370.

Hsu, R. Y. \& LARdy, H. A. (1969). Malic enzyme. Methods in Enzymology 13, 230-235.

Klomkes, M., Altdorf, R. \& Ohlenbusch, H.-D. (1985). Purification and properties of an FADcontaining NADH oxidase from Mycoplasma capricolum. Hoppe-Seyler's Biological Chemistry 366, 963 969.

KORNBERG, A. (1955). Lactic dehydrogenase of muscle. Methods in Enzymology 1, 441-443.

Lanham, S. M., Lemcke, R. M., Scott, C. M. \& GRENDON, J. M. (1980). Isoenzymes in two species of Acholeplasma. Journal of General Microbiology 117, 19-31.

LeEce, J. G. \& Morton, H. E. (1954). Metabolic studies on three strains of pleuropneumonia-like organisms isolated from man. Journal of Bacteriology 67, 62-68.

Lipman, R. P., Clyde, W. A. \& DenNy, F. W. (1969). Characterization of virulent, attenuated, and avirulent Mycoplasma pneumoniae strains. Journal of Bacteriology 100, 1038-1043.

LYNN, R. J. (1960). Oxidative metabolism of pleuropneumonia-like organisms. Annals of the New York Academy of Sciences 79, 538-542.

McGarrity, G. J., Constantopoulos, G. \& BarRANGER, J. A. (1984). Effect of mycoplasma infection on pyruvate dehydrogenase complex activity of normal and pyruvate dehydrogenase complexdeficient fibroblasts. Experimental Cell Research 151, $557-562$.

Neimark, H. C. \& Pickett, M. J. (1960). Products of glucose metabolism by pleuropneumonia-like organisms. Annals of the New York Academy of Sciences 79, 531-537.

Pollack, J. D. (1975). Localization of reduced nicotinamide adenine dinucleotide oxidase activity in Acholeplasma and Mycoplasma species. International Journal of Systematic Bacteriology 25, 108-113.

PollaCK, J. D. (1983). Localization of enzymes in mycoplasma: preparatory steps. Methods of $\mathrm{Myco}$ plasmology 1, 327-332.

Pollack, J. D. \& Williams, M. V. (1986). PP - $^{-}$ dependent phosphofructotransferase (phosphofructokinase) activity in the Mollicute (Mycoplasma) Acholeplasma laidlawii. Journal of Bacteriology 165 , 53-60.

Pollack, J. D., Somerson, N. L. \& Senterfit, L. B. (1970). Isolation, characterization, and immunogen- icity of Mycoplasma pneumoniae membranes. Infection and Immunity 2, 326-339.

Pollack, J. D., Merola, A. J., Platz, J. \& Booth, R. L., II. (1981). Respiration-associated components of Mollicutes. Journal of Bacteriology 146, 907-913.

RAzIN, S. (1963). Nutritional requirements and metabolism of Mycoplasma laidlawii. Journal of General Microbiology 30, 141-154.

RedDY, T. L. P. \& Weber, M. M. (1986). Solubilization, purification and characterization of succinate dehydrogenase from membranes of Mycobacterium phlei. Journal of Bacteriology 167, 1-6.

REED, J. R. \& MUKHERJEE, B. B. (1963). $\alpha$-Ketoglutarate dehydrogenase from E. coli. Methods in Enzymo$\log y 13,55-61$

ReINARds, R., Kubicki, J. \& OHLEnbusch, H. D. (1981). Purification and characterization of NADH oxidase from membranes of Acholeplasma laidlawii, a copper-containing iron-sulfur flavoprotein. European Journal of Biochemistry 120, 329-337.

REJ, R. \& HORDER, J. (1983). Aspartate aminotransferase (glutamate-oxaloacetate transaminase). In Methods in Enzymatic Analysis, 3rd edn, vol. 3, pp. 416-425. Edited by H. U. Bergmeyer. New York: Academic Press.

RODWELL, A. W. (1960). Nutrition and metabolism of Mycoplasma mycoides subsp. mycoides. Annals of the New York Academy of Sciences 79, 499-507.

Rodwell, A. W. \& Rodwell, E. S. (1954). The breakdown of carbohydrates by Asterococcus mycoides, the organisms of bovine pleuropneumonia. Australian Journal of Biological Science 7, 18-30.

Salih, M. M., Simonsen, V. \& ERnø, H. (1983). Electrophoretic analysis of isoenzymes of Acholeplasma species. International Journal of Systematic Bacteriology 33, 16-172.

Slavik, N. F. \& SwITZER, W. P. (1972). Development of a microtitration complement fixation test for the diagnosis of Mycoplasma suipneumoniae. Iowa State Journal for Research 47, 117-128.

SмITH, P. E. (1971). The Biology of Mycoplasmas. New York: Academic Press.

SMITH, T. E. (1968). Escherichia coli phosphoenolpyruvate carboxylase: competitive regulation by acetyl coenzyme A and aspartate. Archives of Biochemistry and Biophysics 128, 611-622.

SRERE, P. A. (1969). Citrate synthase. Methods in Enzymology 13, 3-11.

STITT, M. (1983a). Citrate synthase (condensing enzyme). In Methods in Enzymatic Analysis, 3rd edn, vol. 4, pp. 353-358. Edited by H. U. Bergmeyer. New York: Academic Press.

STITT, M. (1983b). Fumarase. In Methods in Enzymatic Analysis, 3rd edn, vol. 3, pp. 359-362. Edited by H. U. Bergmeyer. New York: Academic Press.

Tourtellotte, M. E. \& JacoBs, R. E. (1960). Physiological and serologic comparisons of PPLO from various sources. Annals of the New York Academy of Sciences 79, 521-530.

Tryon, V. V. \& Pollack, J. D. (1984). Purine metabolism in Acholeplasma laidlawii $\mathbf{B}$ : novel PP.dependent nucleoside kinase activity. Journal of Bacteriology 159, 265-270.

TRYON, V. V. \& PollaCK, J. D. (1985). Distinctions in Mollicutes purine metabolism: pyrophosphate-dependent nucleoside kinase and dependence on 
guanylate salvage. International Journal of Systematic Bacteriology 35, 497-501.

VANDEMARK, P. J. \& SMITH, P. F. (1964a). Respiratory pathways in the mycoplasma. II. Pathway of electron transport during oxidation of reduced nicotinamide adenine dinucleotide by Mycoplasma hominis. Journal of Bacteriology 88, 12-129.

VanDemark, P. J. \& Smith, P. F. (1964b). Evidence for a tricarboxylic acid cycle in Mycoplasma hominis. Journal of Bacteriology 88, 373-377.

VANDEMARK, P. J. \& SMITH, P. F. (1965). Nature of butyrate oxidation by Mycoplasma hominis. Journal of Bacteriology 88, 1602-1607.
Williams, V. R. \& LARTigue, D. J. (1969). Aspartase. Methods in Enzymology 13, 354-361.

Wood, H. G., O'Brien, W. E. \& Michaels, G. (1977). Properties of carboxytransphosphorylase; pyruvate dikinase; pyrophosphate phosphofructokinase and pyrophosphateacetate kinase and their roles in the metabolism of inorganic phosphate. Advanced Enzymology and Related Areas of Molecular Biology 45, 85-155.

YoshidA, A. (1969). L-Malate dehydrogenase from Bacillus subtilis. Methods in Enzymology 13, 141145. 